\title{
Kelsen'in Hukuk ve Devlet Teorisi
}

\author{
Yazan: Doç. Dr. Muvaffak AKBAY
}

Avusturya'l ${ }_{1}$ hukukçu Kelsen'in hukuk ve devlet nazariyesi, son zamanların en fazla ùzerinde durulmuş ve münakașa edilmiș nazariyelerindendir. Gerek Almanya'da gerekse merkezî Avrupa'da ve İtalya'da bu görüş tarz, büyük akisler tevlit etmiștir.

Kelsen'in teorisinin XIX uncu yüzyıl Alman pozitivizm cereyanının bir devamı olduğu söylenebilir. Gerber'in kurduğu pozitivizm mektebi, bilindiği gibi, Laband ve Jellinek taraflarından tekâmül ettirilmiș ve hukuk ilmini tarihî, siyasî ve içtimaî unsurlardan ayıklamak amacını gütmüş̧ür. Ayni endișeye Kelsen'de de rastlanır. Ancak, bu sonuncu müellif, hukuk nazariyesini bir takım felsefi esaslara istinat ettirmek suretiyle, bir çok bakumlardan tamamen orijinal fikirler ortaya atmağa muvaffak olmuştur.

A - Kelsen nazariyesi üzerine müessir olan felsefi cereyanlar: Kelsen'in hukuk ve devlet hakkındaki görüş tarzına nüfuz edebilmek için onun mülhem olduğu felsefî cereyanlar üzerinde durmak zarureti vardır. Filhakika bu müiellif Kant'ın ve onun muakkiplerinin, yani bir taraftan Rudolph Stammler'in ve diğer taraftan Marburg mektebi diye anılan néo-kantisme (Cohen, Natrop) cereyanının tesiri altında kalmıș$\operatorname{tir}(1)$.

Kant'in deneyüstï felsefesi, ilk defa olarak Stammler tarafindan hukuk ilmine tatbik olunmuștur. Stammler, bu suretle, bütün içtimấ hadiseleri iktisadi âmillerle izah etmek isteyen ve cemiyetin alt-yap s1nı (infra-structure) iktisadî âmillerin teșkil ettiğini, hukukun, ahlâkın, tarihin daimî bir şekilde bu iktisadî âmillere tâbi olarak değișiklikler arzettiğini ileri süren tarihî maddeciliğe bir tepki yaratmak arzu etmiștir. Stammler'e göre, hukukî nizam, iktisadî olayları takip eden bir üstyapı (Super-structure) değil, bilâkis iktisadî hayatın ve cemiyetin man-

(1) Simonovitch, Les théories contemporaines de l' Etat, Paris 1939, S. 18. 
tıkan kabli bir unsurudur. İktisadî ve içtimaî vakıaların hukuk ile münasebetleri, materyalistlerin iddia ettikleri gibi, bir milliyet münasebeti değildir. Yani hukuk kaidelerinin esasını, sebebini iktisadî âmiller teşkil etmez. Bilâkis, iktısadın, cemiyetin bahis mevzuu olabilmesi için hukuk șarttır. Binaenaleyh, iktisat ile hukukun münasebetinde hukuk başta gelir. Demek oluyor ki hukuk, gerek iktisattan gerekse sosyolojiden müstakil olarak tesis olunabilir.

Stammler'e göre, hukuk bilgisinin șeklî (formel) unsurunu maddî muhtevasından ayırdetmek lâzımdır. Saf hukuk, bizatihi hukuk bir șekiller, kalıplar mecrnuasıdır. Maddî muhteva, hukuk değildir. Her hangi bir fikir hukukî bir şekilde ifade edilmek istenildiği takdirde hukukî kaliplara sokulur. O halde, hukuk felsefesi, hukukî bir tarzda düşünmek için düşüncemizi soktugumuz kalıplar sistemidir. Hukuk mefhurau, haddizatında hiç bir muhtevası olmayan bir düșünce kalıbından ibarettir(2).

Néo-Kantisme cereyanına gelince: Kelsen bu nektebin bilgi teorişinden mülhem olmuştur. Bu mektebe göre, bilginin mevzuunu, o bilgiyi elde etmek için kullanlan metod yaratır. Bilgi, essyanin birbiriyle olan münasebetlerini tesbit etmek olduğuna göre bu miinasebeti meydana koyabilmek için, evvelâ, esyanın hudutlarını tayin etmek lâzımdır. Halbuki tabiatte, huciutları tayin edilmiș șeyler yoktur. Biz aklımız celâletiyle

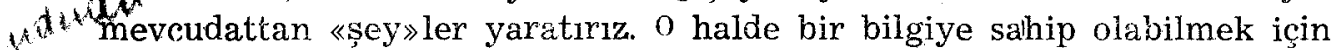
sun'î bir tecrit yapmak zorundayı. Meselâ, bir, at ve üstündeki süvari bir tek «sey» olarak nazarı itibara alınabileceği gibi sadece at veya sadece atın başı veya gözü de nazarı itibara alınabilir (3). Iște bu tecrit bir metoddur. Binaenaleyh, bilginin mevzuunu, kabul edilen metod yaratir. Metod değişirse bilgi mevzuu da değișir. İlmî bir bilgi, muayyen bir metodla elde edilen bir malûmat silsilesi demektir. O halde, bilginin ilmiliği metodun safiyetile ölçülür.

İki türlï bilgi vardır. Birincisi realiteyi «olan»1 tetkik eder ve izah eder. Realiteden maksat, illiyet kanununa tabi maddi ve psișik âlemdir. Bütün tabii ilimler ve sosyoloji bu birinci kısma dahildir. Realiteyi arayan ilimlerin hepsinin metodu aynıdr. İkincisi, ise düsturcu (normatif) ilimlerdir. Bunlar realiteyi, «olan»ı değil ideal șekli, «olması lâtingelen»i ararlar. Hukuk bir normatif ilimdir. Işte bu iki nevi bilginin metodlarmı birbirine karıștırmamak lâzımdır. Aksi takdirde ilmi bir bilgi edinilemez.

(2) Simonovitch. Op. cit, S. 19

(3) Peretiatkowicz. La méthode normative en droit public, Archives de philo. cle $\mathrm{dr}$. et de sociologie jur., 1946, 1.4, S. 230. 
B - Kelsen'in hukuk nazariyesi: İște Kelsen, bir taraftan Alman pozitivistlerinin, diger taraftan. da, Stammler'in saf hukuk nazariyesinin ve néo-kantism cereyanının ortaya attığı: ilmî bilginin bir malûnıat yığını olmayip muayyen bir metodla elde edilen sistemli bir bilgi manzumesi olduğu hususundaki iddianın tesiri altında kalarak hukuk nazariyesini inșa etmiștir.

Kelsen'e göre, saf hukuku elde edebilmek, yani hukuku ahlâkî, sịyasî, içtimaî muhtevasından ayırdederek mütalâa edebilmek için Kant ve muakkiplerinin bilgi teorisini benimsemek zaruridir. Bașka bir ifade ile, saf hukuk teorisinin iki felsefr temel mevzuası (postulat) vardır:

1)-Bilgi metodunun saf olması prensibi: Yani muayyen bir bilgi edinilirken, önümüze çıkacak meseleleri aynı görüş zaviyesinden tetkik etmek ve bu görüș zaviyesini asla değiștirmemek,

(2-Bilgi mevzuunun vahdeti prensipi; yani ilmi bilgi ancak muayyen bir metod sayesinde elde edilir. Metod değiştirilecek olursa mevzu da değișir ve iktisap edilen malûmat ilmi olmaktan çlkar. Filhakika, müellife göre, her ilmin diğer ilimlerin mevzuundan ayrı ve kendine has bir mevzuu vardır ve bir bilginin ilmî bir bilgi olabilmesi için kendisine has metodun ve yalnız o metodun kullanılması lâzımdır.

Izahci ve düsturcu ilimler.- Hukuk ilminin mevzuu, sadece hukuk düsturları (norm) olmalıdır. Çünkü hukukun cevheri, düsturcu (normatif) bir vasfı haiz bulunması başka bir ifade ile «olması lâzımgelen» (sollen) ile meşğul olmasıdır(4).

Kelsen'in normatif doktrini tabiî ve hakikî âlemle kıymet hükümleri âlemi, yani «olan» (Sein-être) ile «olması lâzımgelen» (Sollen -devoir être) arasinda mevcut esaslı ziddiyete istinad eder. Müellife göre, insan bilgisini iki gruba ayırmak mümkündür. Birinciler, șeniyet (réalité) âlemini tetkik ederler ve illiyet prensibine istinat ederek hakikî vakıaların sebeplerini araștırır, müşahede eder ve bu vakıaların birbirini takip etmesini izah eylerler. Bu nevi bilgilere izahcı ilimler (Sciences explicatives) adını vermek mümkündür. Bu sadece «olan» (sein) ile iştigal eden ilimler arasına bütün tabiî ilimleri ve sosyolojiyi sokmak mümkündür.

Ikinciler ise, bilâkis ideal âlemine, vecibeler âlemine tevcih olunmuşlardır. Bunlar hakikatte mevcut olanla iștigal etmezler. Bunların gayesi «olması lâzımgelen» (sollen) hakkında düsturlar, normlar vaz etmektir. Bunlar, vakiaları, realiteyi izah ile mesgul olacak yerde ideal

(4) Simonovitch, op, cit., S, 20.

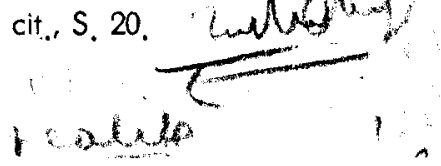


âlemi kurmağa çalıșrlar, fiiliyatta uyulmasa bile uyulması gereken düsturlar, normlar vazederler. Bu kabil bilgilere düsturcu ilimler (Sciences normatives) adı verilir ki, bunlar başta hukuk olmak üzere, ahlâk, mantık; gramer gibi ilimlerdir.

Hukuk düsturcu bir ilimdir.- Kelsen'e göre, hukuk, tamamen ve münhasıran normatif bir ilimair. Ancak, bundan, hukukun; tabiî hukuk mektebinin yaptığı gibi keyfî bir takım hattı hareket düsturları koyabileceği anlașllmamalıdır. Hukuk, bu normların özünü. yani vaz eylediği vecibelerin esasını müsbet hukuktan alır. Hukukun bir «ilim» addolunabilmesi için sırf «olması lâzımgelen» ile iștigal eylemesi ve gayesinin vakıaları değil kaideleri, düsturları metodik bir şekilde tesbit etmekten ibaret bulurması lâzımdır.(5) Hukukun sahası, sadece ideal bir mevcudiyeti haiz olan ve «olması lâzımgelen»i bildiren normlara inhisar eder. Hukuk ilminin, ilmî araștirma mevzuu «norm»dur. Tabiat âlemi, realite âlemi, içtimaî vaikıalar âlemi illiyet kanununa tabidir. Hukuk âlemi ise normlara tabidir. Orada sebep ve neticeyi birbirine bağlayan illiyet kanunu yoktur. (6) Hukuk âlemi, hukuk normunu, insanların ef'aline tatbik eder. Tabiat kanunlariyle hukuk normları arasındaki kesin fark su suretle izah edilebilir: Tabiat kanununa göre A var olan ise B olacak olandır. Hukuk normuna göre A var olan ise B olması lâzım gelendir. Felsefi bakımdan, «olan»lar âlemi ile «olması lâzımgelen»ler âlemi arasındaki zıddiyet tabiat ile düşünce arasındaki zıdiyetten bașka bir șey değildir.

Pozitivizm ve formalizm.- Kelsen'e göre, hukukçu, müsbet hukuk nizamlariyle meşgul olur. Hukukun umumî teorisini vücuda getirebilmek için bütün müsbet hukuk nizamlarına müşterek olan prensipleri meydana çlkarmak lâzımdır. Bu neticeye varmak için de hukukun șeklini mütalâa etmekten ve şeklî bir takım anlamlar tesbit etmekten başka çare yoktur. Zira, ancak her türlü maddî muhtevadan tecerrüt etmek ve sadece șekil ile messgul olmak sayesindedir ki bütün müsbet hukuk nizamlarına müșterek olan cihetler elde edilebilir. Bir hukuk nizamından diğerine muhteva değișse bile, sabit kalan yalnız șekildir. Hukukun umumî teorisi ancak sekli (formel) bir teori olabilir(7).

Saf hukukta gaî mülâhazaların yeri yoktur. - Saf hukuk (droit pur) ilminde her türlü siyasî, sosyal, ahlâkî unsurların yeri yoktur. Cuünkü, müellife göre, bunlar hukuk dișı mefhumlardır. Hukuk ilmi, hukuku ha-

(5) Peretiatkowicz, op. cit, S. 227

(6) Kelsen, Les rapports de sytème entre le dr. interne et le dr. inter. pub., Recueil des Cours, 1926, C. 14, S. 234

(7) Simonovitch, op. cit. S, 21 . 
kikatte olduğu gibi ele alır. ve izaha çalıșır. Hukukun âdil olduğunu isbata ve gayri âdil olduğunu iddiaya kalkıșamaz. Hukuk ilmi, âdil hukuku değil hakikî ve mümkün hukuku bilmek ister. Kelsen'ịn fikrince, bir kamun için: âdil veya gayri âdil demek hukukcunun değil ahlâkcının işidir. Kanun vazını tenkit ise siyaset adamını ișidir.(8) Saf hukuk teorisi realist ve şeklîdir. Onda 'gaî (téléologique) mülâhazaların, ideolojilerin ve tabiî hukukun yeri yoktur. Hukuk âlemi «hukukî hâdiselerin bir geometri»sinden bașka bir şey değildir.

Hukuk normunun mümeyyiz vasfi. - Kelsen'e göre, hukuk ilmi bir hukuk normları sistemidir. Müsbet hukukun ihtiva eylediği düsturlar, ideal bir sistem, normatif bir vahdet teşkil ederler. Hukuk normlarının bir takım vasıfları vardır ki, bu normların bir araya gelmelerinden ibaret olan hukuk sistemlerinde de aynı vasıflara rastlanir:

1 - Hukuk normu «olması lâzımgelen»i (Sollen)i bildirir. Hukuk düsturunun manayı vücudu insanların yapmaları veya yapmamalam lâzımgelen hususları açılklamaktır. Bu bakımdan hukuk normunu, diğer normatif ilimlerin normlarından ayirdetmeğe imkân yoktur. Zira gerek ahlâki, gerekse dinî düsturlaı da hukuk düsturu gibi «olması lâzımgelen»i bildirir.

2 - Hukuk normunu, diğer normlardan ayırdeden muhtevası değil, zecrî oluşudur. Hukuk normu her hangi bir muhtevaya sahip olabilir. Bunun ehemmiyeti yoktur. Ancak, ona hukukîlik vasfını veren, zecrî bir düstur olmasıdır. Hukuk kaideleri zecrî kaidelerdir ve zecir her zaman fiilen mevcut olmasa dahi her hukuk normunda zecrî vasıf vardır. (9)

Hukuk normu nevileri.- Kelsen, iki türlü hukuk normu vardır, diyor. Bunlardan bir kısmı insanlara bazı hareketleri emir ve bazılarını menederler. Müellife göre bunlar «ikinci derecede» normlardir. Diğer bir kisım ise bu ikinci derecede normlara itatsizlik halinde devlet organlarına bir müeygido tbikini emreden normlardır ki bunlar «birinci derecede» normlardir.

Hakikatte, ferdleri şu veya bu șekilde harekete icbar eden ikinci derecede normlar değil birinci derecede normlarđ̈r. Çünkü, müeyyideye merbut hukuki mükellefiyet ancak birinci deecedeki normlarda vardir. Binaenaleyh, sade birinci derecedeki normlar hukukî normlardir. Zira yalnız onlar bir hukukî mükellefiyet ihtiva ederler.(10) Kelsen'e göre, insan tasarrufları şu düsturun tatbikiyle hukukî bir mahiyet alırlar:

(8) Coste-Floret. Les problèmes fondamentaux du droit, Puris 1946, S. 37

(9) Simonovitch, op. cit., S. 25.

(10) Simonovitch, op. cit., S. 26 ve Kelsen, Les rapports, S. 244. 
«Derpiş edilen şartlar tamam olduğu takdirde bu tasarruflar hukukí birer tasarruf addolunur ve hukuk normlarının tesbit eylediği neticeler tatbik edilir.»

Görülüyor ki, hukuk normu, insan tasarruflarmı takdire yarayan, yani bu tasarrufların hukukî olup olmadıklarını belirten bir șekil bir kalıp. tan bașka bir șey değildir. Meselâ bir idam bir katil telâkki olunamaz. Çünkü, kanuna göre, bu müeyyide bir memnu fiilin hukukî neticesidir ve hukukan bu memnu fiil idam cezasının tatbiki için bir șarttır. Yani kanun: «hemcinsini şu şartlar altında öldüren idam edilir» diyor. Kanunun tesbit eltiği şartlar altında bir adam öldürme fiili vaki olmușsa ortada idam cezasının yerine getirilmesi için bir hukukî șart var demektir. Binaenaleyh idam cezasının tatbiki bư hukukî șartın tevlit eylediği bir hukukî neticedir ve bir katil addolunamaz.

Normlar sistemi.- Insanların fiillerine hukukilik vasfını veren nasil hukuk normu ise normların hukukilik vasıfları da diğer normlardan ve nihayet temel-norm'dan, temel düsturdan (Ursprungsnorm) istidlâl edilmeleri keyfiyetidir. Meselâ, muayyen bir șahsın veya meclisin derpiș edilmiş şartlar altınđa yaptığı fiiller hukuk normları, yani kanun, addolunur. Hukuk normları. birbirinden iștikak eder. Norm, asla vakıadan çlkmaz. Her norm, kendisine üstün olan bir normdan istidlâl olunur ve o normdan da diğer bir takım normlar çlkarllır. Bu suretle, ortada piramide benzeyen bir normlar meratibi vardır ki bunun zirvesinde bütün normların mer'iyetini sağlayan ve normlar mecmuasının vahdetini teşkil eyleyen temel-norm vardır. Bu temel düstur, hukuk nizamının aslî düsturu olduğuna göre, diğer normlardan farklı bir cevhere sahip olmalıdır. Fakat bu temel normun mahiyetinin araştırılması hukuk ilminin sahası dișında kalır.(11)

Tekcilik.- «Ilmî bilgi, bilgi mevzuunun vahdetini gerektirir» prensibinden hareket eden Kelsen, hukuk sahasında mutlak hukukî bircilik'e (monisme) varmaktadır. Müellif, bütün hukukî mefhumları, hukuk ilminin her sahasına tatbik ettiği mutlak normatif monizm'e ircâ eylemeğe muvaffak olmuştur. Bu sayede, Kelsen sisteminde hukuk, müsbet hukukî normlar sisteminden bașka bir șey değildir.

Filhakika, Kelsen dahilî hukuk ile devletlerarsı hukuku arasında bir ikilik kabul etmez. Devletlerarası hukuku normları müellife göre iç hu-

(11) Simonovitch, op. cit, S. $27 \cdot 28$. 
kuk normlarına üstündür ve onlara tesir eder. Binaenaleyh bunlar arasinda bir ikilik bahis mevzuu olamaz.(12)

Amme hukuku ile hususî hukuk arasındaki tefrik de Kelsen nazarında sun'i bir tefriktir ve ortadan kaldırılmalıdır.

Hukuk süjesi ile bizatihi hukuk, objektif hukuk ile sübjektif hukuk arasındaki ikilik de mevcut değildir. Hukuk süjesinin hukukî nizamdan ayrı, farklı bir mevcudiyeti yoktur. Hukuk süjesi hukukî nizamın topyekûn veya kısmî bir șekilde șahıslandırılmıș halidir. Sübjektif hukuktan farkłr đẹ̆iTdïr. Sübjektif hukuk, hususî bir șahsin zaviyesinden objektif hukukun görünüşüdür. Sübjektif hukuktan hukuk normunun șu veya bu șahsa tatbikini anlamak lâzımdır. Hukuk âleminde yalnız normlar ve normlar sistemi vardır. Hukukî șahıslar veya hukuk süjesi adı verilen șeyler, hakikatte hukukî «emir»lerden başka bir şey değildir. Umumiyetle sübjektif haklar müsbet hukuk kaidelerine müstenit bir takım salâhiyetlerdir ki bu sayede bir kimse diğer bir kimse tarafından ika olunan bir fiil neticesi maruz kaldığ zarar ve ziyanın tazminini talep edebilir. Sübjektif hak, objektif hukuktan müstakil değildir. Bilâkis ona istinat eder (12).

Nihayet, müellife göre, devlet ile hukuk arasında da ikilik yoktur. Devlet, hukukî nizamdan, hukukî nizamin müş̧hhas șeklinden bașka bir șey değildir.

C - Kelsen'in devlet nazariyesi- - Kelsen, devlet ile hukuku birbirinden ayrı iki vakıa gibi mütalâa eden klâsik nazariyeyi «bilgi mevzuunun vahdeti» postulat'sına rialyet etmediği için tenkit ediyor. Devletin hukukî mefhumuna varabilmek, ancak; normatif metoda baş vurmakla mümkündür. Müellife göre, devleti, klâsik nazariye taraftarlarının yaptıkları gibi sosyal bir realite olarak ele almamak lâzımdır. Devleti bir realite olarak kabul eden nazariyeler onun cevherini kavrayamamıșlardır. Zira devlet, umumiyetle ileri sürüldüğü gibi «teşkilâtlanmış bir kudrete tabi insan topluluğu» değildir. Devlet, otoritesine ferdlerin tabi oldukları bir «nizam dır. Bașka bir söyleyiş șekliyle devièt «insan faaliyetlerinin tanziminden» ibarettir (13).

Devletin sosyolojik ve hukukî teorilerini birbirinden ayırdetmek lâzımdır.- Eğer diyor Kelsen, devletin realite plânında ve hukukun da

(12) Kelsen, op. cit., S. 263 ve devamı, Théorie générale du droit international public, Recueil des cours, 1932, C. 42, S. 121.

(12) Kelsen, Les Rapports, S. $244 \cdot 24 \dot{5}$

(13) Kelsen, Les Rapports., S. 234 ve 249. 
idealite plânında olduğunu kabul edersek bu takdirde iki türlü bilgi mevzuu önümüze çıkar. Zira, biri «olan»1 diğeri «olması lâzımgelen»i tetkik eden bu iki farkl metod ortaya birbirinden aym iki bilgi mevzuu kor:(14) Bunlardan birincisi, illiyet kanununa tâbi sosyal realiteyi inceler. Diğeri ise, yegâne hukukî metod olan normatif metodla, devletin hukukî mahiyetini araştırır. Yani birincisi, insanların cemiyet dahilindeki hakikî faaliyetleri üzerinde durur ve insan faaliyetlerine müessir olan sebepleri ve kanunları tesbit eder. Íkincisi ise bilâkis, insanların nasıl hareket etmeleri lâzımgeldiğini ve bu bakımdan hareketlerini hangi kanunlara tâbi tutmaları icabettiğini tetkik eder (15). Bu suretle hususî normlardan bașlayarak gittikçe daha umumî normlara varan bir normlar (düsturlar) sistemine varilır ki bu normların bir tabiat kanunu olan illiyet kanuniyle hiç bir alâkaları yoktur. İște bu iki ayrı metodun birincisiyle devletin sosyolojik nazariyesi, ikincisi ile devletin hukukî nazariyesi elde edilir. Böylelikle, devlet hakkında birbirinden farklı iki mefhum ortaya çlkar:

1 - Tümevarım metodu ile ve illiyet kanununa istinaden elde edilen sosyolojik mefhum.

2 - Devletin normatif mefhumu.

Ancak, birbirine zıd olan bu iki mefhum aynı zamanda kullanıldı mı, Kelsen'e göre «bilgi mevzuunun vahdeti» ortadan kaybolur. Mademki, hukuk ilminin mevzuu, yalnız normatif metodla elde edilebilir; o

- halde hukuk bakımindan devlet bizzat hukuktan yani hukuk normları sisteminden başka bir șey olamaz (16).

Devlet bir normlar sistemidir.— Görülüyor ki, «metodun safiyeti» ve «bilgi mevzuunun vahdeti» gibi felsefî mevzulardan hareket eden müellif, mantıkan devlet ile hukukun ayniyeti neticesine varmaktadir. Kelsen'e göre bir hukukçu nazarında devlet bir hukukî normlar mecmuasından balskka bir șey olamaz. O, hukuk ilmi için devlet sosyolojisinin lüzumuna kani değildir. Hattâ, devletin izahını realitede «olan-Sein» âleminde araştırmak saçmadır. Çünkü, devlet sosyolojisi ile devletin hukukî

(14) Simonovitch, op. cit., S. 36.

(15) Kelsen, Les rapports., S. 242.

(16) Simonovitch, op. cit., S. 37 Kelsen devlet ile hukukun avn sev olduğu fikrinin ilim tarihinde baska bir misali buiunduğunu söylüyor. Filhakika, Allah ile dünya Iveya tabiat) arasındaki münasebet meselesi tıpkı devlet ile hukuk arasındaki münasebet gibi ilk önceleri iki avn bütün arasında mevcut bir bağ olarak ele alınmıștır. Neden sonradir ki Allah fikrinin haddi zatında, bir kanunlar sistemi olarak kabul edilen tabiatın şahılandırılmıs seklinden baska bir sey olmadığ: anlasılabilmistir. Tıpk: onun gibi devlet de hukukî normalar sisteminin müsahhas şeklinden ibarettir. Kelsen, op. cit, S. 247. 
teorisi arasında müşterek hiç bir nokta yoktur ve bunların sahaları başkal başkadır. Filhakika, birincisi realite ile «olan»lar, vakıalar âlemi ile meşgul olur. Halbuki ikincisi «olması lâzımgelen» sollen âlemi ile, normlarla iștigal eder. Kelsen, «devletin umumî nazariyesi hususunda bir görüş̧ adlı makalesinde, devletin hukukî teorisinin devletin sosyolojik teorisi ile tamamlanmak istenilmesinin hususî hukukun insanın psikolojisi ve biyolojisi ile tamamlanması teșebbüsü kadar gayri mantıkî olduğunu söylemektedir. Unutmamalıdır ki, diyor müellif, hukukî normların muhtevasını biyolojinin, psikolojinin meșgul olduğu «insan» in fonksiyonları teşkil eylemez (17).

Hûlâsa, Kelsen'e göre devlet, tabiat kanunlarına tâbi sosyal veya psikolojik bir realite değildir. Bilâkis devlet ideal bir şekil, saf bir normlar mecmuasıdır. Devlet normatif hukukî nizamin bizzat kendisi veya başka bir ifade ile insan faaliyetlerinin tanzim edilmesidir.

Devleti diğer normatif nizamlardan ayırdeden mümeỳyiz vasıf.Devletin normatif zasfi, , onu diğer sosyal topluluklardan ayırdetmeğe kâfi değildir. Çünkü, bunlar da birer normlar sistemidir. Her sosyal bağ normatif bir bağdır. Cemiyetin nesci «mükellefiyet»lerden dokunmuştur. Yani, her hangi bir insan topluluğunu hukukçu gözüyle tetkik edersek, o topluluğun bir normatif nizam olduğunu ve bu nizamın o topluluga dahil olan fertleri muayyen bir hareket hattı takip etmeğe sevk eden bir sürü mükellefiyetler doğurduğunu görürïz (18).

Devlet nizamını diğer normatif nizamlardan ayırdeden mümeyyiz vasıf zecri tesis etmesi, devlet normlarını, muayyen şartlar altında (devlet organı olarak) bir ferdin diğer bir ferd hakkında zecrî tedbir alacağını ifade etmeleridir. Yani, eğer bir ferd muayyen bir sekilde hareket edecek olursa ve meselâ muayyen bir şeyi yapar veya yapmaktan imtina ederse, devletin organı olan diğer bir ferd ona karşı zecrî tẹibir alır. Kelsen, bu tedbiri ikiye ayırmaktadır: Ceza ve cezanin tatbiki. Bu zecir tehdidinin gayesi, insanları zezrin tahakkukuna, tatbikine meydan vermiyecek șekilde harekete sevketmektir (19).

Demek oluyor ki, müellife göre, devlet bir ferde, diğer bir ferd tarafından muayyen bir zecrin hangi șartlar altında tatbik olunabileceğini tanzim eden normmlar sistemidir. Ancak, bu zecrin fiilen tatbik edilip edilmediği ve yine bu zecrin derecesi hukuku alâkadar etmez. Kelsen

(17) Simonovitch. op. cit., s. 38

(18) Kelsen, Les rapports.., s. 241.

(19) Kelsen, Les rapports.,, s. 242, 
zecri hukukun muhtevası olarak ele almakta ve onun fiilen tatbik edilip edilmediğini hukuk dişı addetmektedir.

Müellif, zecri hukuk normunun bir vasf $f_{\mathfrak{l}}$ olarak kabul etmek suretiyle klâsik hukuk nazariyesiyle birleșmekte, fakat klâsik müellifler gibi zecri hukukun fizik bir unsuru olarak ele almamaktadır. Yani Kelsen, hukuk normunun esası olarak doğrudan doğruya zecrî tedbiri değil de zecrî tedbir alınması prensibini kabul ediyor.

Devlet muayyen bir teșkilâta sahip olmalıdır.- Devlet bir hukukî nizamdır, fakat her hukukî nizam devlet değildir. Bir hukukî nizamın devlet olabilmesi için, hukuk normlarını ortaya koymak ve tatbik edebilmek fonksiyonlarını haiz hususî organlara sahip bulunması lâzımdır.

Devletten önceki cemiyetlerde, hukuk nørmları, örf hukukundan istidlâl olunur ve bu normlar muayyen bir teșkilâta tabi olmayan ferdler tarafından tatbik edilirdi. Zamanla merkezî bir kudret belirmiș ve teșkilâtlanmiștır. Evvelâ merkezi idare, daha sonra mahkemeler ve nihayet teşrii iktidar vücut bulmuştur. Iște, hakikî devlet bu organlarla birlikte meydana çıkmıştır (20).

Devlet nizamının vasıfları mer'iyet (validité) ve miiessiriyet (efficacité).- Kelsen'e göre devlet nizamı mer'i, hukukan muteber bir nizam olmalıdır. Devlet nizamına mer'iyetini sağlayan nedir? Bazı müellifler, devleti tebaayı teşkil eden insan topluluğuna üstïn bir kuvvet olarak ele almışlar ve devlet nizamının mer'iyetini bu kuvvete istinat ettirmișlerdir. Diğer bazı müellifler ise devletin bir «irade» olduğunu veya devletin bir «iradesi» bulunduğunu ileri sürmüșlerdir. Onlara göre, bu irade fertlerin iradesinden ayrıdır. Hiç şüphesiz devletin bu iradesi veya bir irade olan devlet vasita olarak ferdleri ve onlarin iradesini kullanır. Fakat devletin iradesi ona tabi ferdlerin iradeleriyle karıștırılamaz, hattâ bu idarelerin mecmuu da değildir. Devletin iradesi ferd iradelerinin yekûnundan fazla ve ona üstündür. İste devlet nizamının mer'iyeti bu üstün iradeye istinat ettiği içindir.

Kelsen. bu iki görüșü de reddediyor. Ne kuvvet ne de irade hukuk yaratamaz. Cü̈nkü her ikisi de birer «vakıa»drr. Bir vakıadan asla hukukî bir mükellefiyet doğmaz. Vakıalar âlemi yani «olan»lar âlemi ile «olması lâzımgelen»ler âlemi birbirinden tamamen ayrıdır. Birinden öbürüne geçmeğe imkân yoktur.

(20) Kelsen, Les rapports. 245.246 burada Kelseri'in devlet mefhumuna, organ ve teskilâtlanma aibi normatif olmayan unsurlar soktuğunu görüyoruz. Bk. Simonovitch, op, cit. S. 43 
O halde bir hukuk normunun mer'iyeti, yeni bir hukuk normunun bir mükellefiyet yaratması keyfiyeti ancak daha üstün bir norma istinat etmesinden tevellüt eder. $O$ norm da mer'iyetini kendinden daha üstïn diğer bir normdan alır. Bu suretle normdan norma anayasalya kadar çıkılabilir. Ancak anayasa mer'iyetini nereden alacaktır? Kelsen buna: anayasaya üstün olan bir normdan: «temel - normdan» cevabinı veriyor. Bu temel - norm müsbet hukukta yoktur. Bu bir «mantıkî faraziye»dir. Anayasanın üstünde bizim hukukcu gözüyle göremiyeceğimiz bir temel-normun, aslî bir normun mevcudiyetini farazî olarak kabul etmekliğimiz lâzımdır. Iște bu temel - norm bütün hukuk sisteminin mer'iyetini sağlar, hukukun esasını temelini teșkil eden bu farazî normdur. Aksi takdirde, yani temel - norm faraziyesi kabul edilmediği takdirde, devlet nizamının meriyetini makul bir esasa istinat ettirmeğe imkân yoktur.

Hûlâsa, müellife göre, müsbet anayasanın fevkinde farazî bir esas teşkilât, bir kesin buyruk (impératif catégorique) vardır ki, neticede hukukun temelini, devlet nizaminın esasını ve meriyetini teșkil eden ve sağlayan odur (21).

Devlet nizaminin mer'iyeti demek bu nizamın ortaya koyduğu emir ve nehilere uyulmanin bir mükellefiyet olarak telâkki edilmesi demektir. $\mathrm{Bu}$ mükellefiyet tamamen mantıkî, aklî bir mükellefiyettir. Yani, ferdlerin hareketlerini muayyen normlara uydurmalan lüzumu, fiiliyattal fertler o normlara her zaman riayet etmeseler dahi, ortadan kalkmaz. Hattâ, bir hukuk normunun mer'iyeti her zaman ve behemahal fiiliyatta o norma riayet olunmasinı tazammun etmez. Insanlarin ef'aliyle, kaidelerin icabatının mutlak bir mutabakatı gerekli değildir. Hattâ, böyle bir mutabakatın normun mahiyetini değiștireceği bile ileri sürülebilir. Zira, sosyal vakıalarla hukuk normu. arasında bir mutabakat olduğu takdirde bu bir hukuk normu olmaktan çlkar, tabiî bir kanun, illiyet kanununun tevlit ettiği bir münasebet olur. Demek oluyor ki, norma bazı defa aykırı hareket edilmesi onun mer'iyetini haleldar etmek şöyle dursun hukuk normunun normatif vasfını takviye eder.

Buna mukabil, eğer bir hukukî norma veya nizama hiç riayet edilmiyorsa, bașka bir fiade ile, bư normlar nizamının süjeleri o nizamın icaplarına hiç riayet etmiyorlarsa, bu nizamın mer'iyetini iddia etmek saçma olur.

$\mathrm{Bu}$ suretle Kelsen, hukukî nizamm meriyetine iki hudut tayyin etmektedir. Bir asgarî had ki bunun altında hukukĩ nizamın mer'i addo-

(21) Coste - Floret, op. cit., S. $39-40$. 
lunmasına imkân yoktur ve bir azamîhad ki bunun üstünde mevzuubahis nizam normatif bir nizam olmaktan çıkar ve tabiî bir nizam olur.

Devlet nizazminin mer'iyeti ile vakialar arasındaki münasebeti, müellife göre, șu șekilde tespit etrnek lâzımdır: bir devlet nizamını muteber ve mer'i addedebilmek için o nizama tabi olanların bir dereceye kadar o nizamın icaplarına uymaları lâzımdır. Aksini iddia etmek doğru olmaz. Hiç şüphesiz bugün dahi, meselâ Çarlık nizamının hâlâ Rusya'da mer'i olduğunu iddia eden bazı inatcllara rastlanır. Bunlar, ihtilâldenberi cereyan eden hadiseleri (hukukî nizam gayri meșru yollardan tadil edildiğine göre) hukuka aykırı addederler. Bu, mânasız bir düşünce tarzıdır. Zira, halen mevcut hiç bir șeyi meșru telâkki etmeyen bir nizamın, mer'iyetini iddia ne ifade eder? Fakat buna mukabil, normatif nizama tabi olanların ef'al ve harekâtının onun icablarına mutlak bir mutabakatını da talep etmemek lâzımdır. Çünkü, bu normlara aykırı hareket etmenin de «mümkün olabilmesi» gerektir. Aksi takdirde bu bir normatif nizam olmaz.

Hülâsa, realite normatif nizamın tam bir makesi olamaz. Bununla beraber, gerçek hayatta bu ideal șekil ile asgari bir müșabehet arzetmesi zaruridir (22).

Devlet nizamı, sadece mer'i değil, aynı zamanda müessir (efficace) bir nizam olmalıdır. Yani, bu nizama yalnız hukukan riayet edilmesinin lâzımgelmesi káfi değildir. Ona fiilen de az veya çok riayet olunmalıdır. Ancak burada bir yanlıș anlayıșa meydan vermemek lâzımdtr. Hakikatte müessiriyet, hukuk mefhumuna girmez. Insanları hukuk normlarına itaat ettiren, bizzat bu normlar değildir. Fertler, hukuk normlarını benimserler, bu normlar insanların șuurunda yer eder. Insanlar bu normları «düșünürler». Iște müessiriyeti sağlayan bu düșüncedir. Zira, bu düșünce, ferdleri; faaliyetlerini hukuk normlarına uygun bir hale sokmağa sevkeder. Meselâ bir kimsenin hirsızlık etmek arzusuna kapıldığını tasavvur edelim. O kimsenin hatırına devletin «hırsızlık etmiyeceksin» șeklindeki emri gelir ve bu düșünce onu hırsızllktan vaz geçirir.

Haddizatında hukuk normu psikoloji - dıșı bir șeydir. «Olması lâzımgelen»i ifade eder. Bir normun mer'iyeti ile tabiatın determinizmine tabi her hangi bir șeyin realitesi arasında hiç bir münasebet yoktur. Fakat «norm fikri» tamamen psikolojiktir, bir vakıadır. Binaenaleyh, sebep veya netice olabilir. Müessir olan. yani ferdlerin faaliyetlerini norma uydurmalarinı sağlayan bu «norm fikri»dir. Binaenaleyh «mer'i» olan,

1221 Kelsen, Les rapports., s. 237 
yani uyulması gereken norm ile, o normun ferdlerin faaliyetlerine tatbikini sağlayan, yani o normu müessir kılan, şuurumuzdaki intibainı sarih bir şekilde birbirinden ayırdetmek lâzımdır (23). Görülïyor ki; devlet nizamı sadece mer'i olan değil, fakat aynı zamanda fiilen tatbik edilen, müessir olan bir nizamdır. Ancak bundan, devlet nizamının tabiî nizama mümasil olduğu neticesini çıkärmamak lâzımdir.

İnsanların, devlet nizamına niçin riayet ettiklerini tesbit etmek güçtür. Bununla beraber, denilebilir ki, ekseriya veya daima münhasıran devletin emrini düșündükleri için değildir. Ferdleri suç ișlemekten alıkoyan ekseriya dinî veya ahlâkî mülâhazalardır. Yani ferdler, sadece devletin koyduğu kaideye bağlı olan müeyyide korkusu ile değil, fakat, Allaha inandıklari için, hemcinslerinin iyiliğini veya etraflarının kendilerine karşı göstermekte olduğu itibarı sarsmamalğı düşündükleri için devletin emirlerine riayet ederler.

Devlet kudreti- - Kelsen'e göre, devlet kudreti devlet nizamı hakkında beslenen kanaatlerin muharrik kuvvetinden başka bir şey değil$\operatorname{dir}(24)$. Devlet nizamı ise, muayyen bir ülke üzerinde muayyen bir zaman için (yani devletin devamı müddetince) mer'i olan hukukî normlar mecmuașidır.

- Devlet kudretinin cevheri ferdleri devlete tabi kılmaktır. Devlet, bu kudret sayesinde ferdlere hükmeder, yani devlet kudreti ferdleri devletin tebaası yapar. Fert için devlet, itaat edilmesi mecburi bir nizam, normatif bir nizamdir (25).

Devlet kudreti sadece bir vakıa değildir. Eğer böyle olsaydı illiyet kanununa tabi olurdu. Vakıa, bir ferdin —irade beyaniyle veya șiddet istimaliyle- diğer bir ferdin ef'alini tanzim etmesi esasında her hangi fizik bir sebepten ayırdedilemez. Eğer devlet kudreti sadece bu tarzda bir müessiriyete sahip olsaydı devlet ile tebaa arasındaki münasebetleri diğer tabibî hadiselerden ayırdetmeğe imkân olmaz ve bu münasebetler illiyet kanununa tabi münasebetlerden farksız olurdu. Bu tarzda bir anlayıș, nihayet, doğrudan doğruya hakkı kuvvețin yarattı̆̆ın kabule götürür.

Halbuki, devletin «kudreti» veya «buyurma' kudreti» dediğimiz zaman, devletin veya onu temsil eden șahsın veya șahısların sadece fiilen emretmek kuvveti, diğer ferdlerin faaliyetlerine müteallik bir irade beyan etmek kuvveti olduğunu değil, fakat aynı zamanda, bunu yapmak

(23) Kelsen, Les rapports.., S. 236

(24) Simonovitch, op. cit., S. 48

(25) Kelsen, Les ropports.., S. 252 
selâhiyetine de sahip bulunduğunu ve buna mukabil yalnız ferdlerin fiilen devlete itaat ettiklerini değil fakat itaat etmeleri lâzımgeldiğini, buna mecbur olduklarinı anlariz.

Bütün bunlar, ayrıl zamanda hem normu vaz'edenin hem de o norma tabi olanın hareketlerini tesbit eden bir nizam sayesindedir (26). Amme kudretinin neticesi, ferdleri diğer ferdlere tabi kılmak değil, fakat ferdleri onlara bir mükellefiyet yükleyen nomalumalım. Eğer «devlet=normatif nizam» anlamı terkedilecek olursa, devletin mevcudiyetini inkâr ve sadece maddî kuvvet münasebetlerini kabul eden anarşistlerin görüș tarzlariyle birleșmiș olur. Halbuki devlet ile ferdlerin münasebetleri hukukî münasebetlerdir.

C - Kelsen'in hukuk ve devlet nazariyelerinin tenkidi.- Kelsen'ın açmış olduğu normativizm çı̆̆ırı, muhtelif cephelerden çok ağır tenkitlere maruz kalmıştır. Bilhassa Duguit ve Hauriou gibi Fransız müellifler Kelsen doktrinine şiddetle itiraz etmişlerdir. Bundan başka, normativizmin menșe memleketi Avusturya olmakla beraber bu nazariye Avusturya'da da büyük bir mukavemete maruz kalmıștır. Bașta Sander olmak üzere, Othmar Spann, Hold-Ferneck, Erich Voegelin gibi bir çok Avusturyalı hukukçular Kelsen'in hukuk ve devlet nazariyesini tenkit etmişlerdir (27).

1 - Her şeyden önce, Kelsen'in takip ettiği metodu ve kabul ettiği bilgi nazariyesini bir çok müellifler lüzumundan fazla cezrî bulmaktadırlar. Ezcümle (metod bilginin mevzuunu yaratır) postulat'sı așırı bir telâkkinin mahsulüdür. Hiç şüphesiz, bilgi edinen kimsenin mantıkı ile bilgi mevzuu arasında bir münasebet vardır. Ancak, tutulan metod, bilgi mevzuunu yaratmaz. Belki o mevzuu, tetkik edilebilecek diğer mevzulardan ayırdeder. Yani, insan akli obje yaratmaz, diğer mevcudattan ayırdedilmiș, obje mefhumları meydana kor.

Aynı objenin iki ayrı zaviyeden tetkik olunamıyacağı da münakașa götürür. Bir kimse, bir arsa satın alacak olursa bu arsanın evvelâ hukukî durumunu, yani meselâ, ipotekli olup olmadı̆̆ını; daha sonra yine aynı arsanın ziraate elverişli bulunup bulunmadığını ve yine o arsanın bulunduğu mahallin estetik hususiyetlerini pekâlâ inceliyebilir. Şüphesiz, bu kimsenin dikkati, tetkik zaviyesine göre, bașka başka unsurlar üzerinde düracaktır. Bunun neticesi olarak, her defa, önüne yeni bir obje çıktığı belki nazarî olarak kabul edilebilir. Fakat, hakikatte, bütün bu unsur-

(26) Kelsen, Les rapports.., S. 253.

(27) Simonovitch, op. cit, S. 109. 
ları aynı objenin ihtiva etmekte olduğunu unutmamak lâzımdır (28). Bilhassa sosyal ilimlerin mevzular birbirlerine o derece giriftdirler ki, metod uğruna realitoyi parçalamağa kalkışmaks, trzi nătamam ve yanlış fikinlere-sevkeder.

Kaldı ki, hakikat halde «olan» ve «olması lâzımgelen» âlemler arasında Kelsen'in tevehhüm ettiği așılmaz uçurum yoktur. Norm ile realite birbirinden ayrı değildir. Realite normu intiva eder. Realite ile normun birbirleriyle münasebetleri vardır. Mevcut olan șeylere, mevcut olması lâzımgelen şeylerin, tahakkuk etmiș kısmı nazariyle bakılabilir. Zira; realiteye istinat ederek norma varılır ve normun çekirdeği realitedir (29).

Gerek hukuk ve gerek devlet mefhumlarinin hem «olan» hem de «olması lâzımgelen» alemleriyle münasebeti vardır (30). Görülüyor ki, sosyolojik metodu hukukî metodun zıddı olarak kabul etmek hatadır. Sosyolojik metod hukuk sahasında bir yardımeı metoddur. Sosyal realite, sosyal hadiseler ve bunların tabi olduğu kanunlar bilinmeden hukuka, normlara varilamaz.

2 - Kelsen'in așırı pozitivizm ve formalizm'ine en fazla itiraz eden Hauriou olmuştur. Fransız üstadına göre, böyle bir noktainazar kabul edildiği takdirde hukukçunun vazifesi sadece mevcut ve müsbet hukuk ile meşgul olmaktır. Hâkim için, hukukçu için yeni hukuk kaidesi yaratmak yolu kapanmıstir. Bu takdirde, tabiî hukuk, tabiî mükellefiyet; adalet prensipleri hukukçu için artık bahis mevzuu olamıyacak ve hukukçu sadece müsbet hukuka müracaatla iktifa zorunda kalacaktır. Bu boşluk o derece tehlikelidir ki, Kelsen bile bunu farazì bir anayasa (veya temel-norm) ile doldurmak istemiştir. Bu temel norm henüz müsbet hukuka girmemiş prensipleri ihtiva etmekteiir. Ancak, burada iki şı vardır: hâkim bu temel normu ya nazarı itibara almiyacak veya alacaktır. Almadiğ 1 takdirde, temel normun hiç bir rolü yoktur ve binaenaleyh tehlikeli boșluk mevcut kalmaktadır. Aldığı takdirde ise Kelsen sisteminin mantıkî insicamı ortadan kalkmaktadır. Çünkü, bu temel norm șeklî hukuktan maldut değildir. Halbuki Kelsen, sistemini sadece müsbet ve şeklî hukuk normlarına istinat ettirdiği iddiasındadır. Bundan başka hukukun formel anlamı, pratike de tesir edecek ve hukukçuları ve bilhassa hâkimleri tıpkı «Figaro'nun düğü»nünde Beaumarchais'nin yarat-

(28) Peretiatkowicz, op. cit, S. 230

(29) Simonovitch, op. cit., S. 119

(30) Duguit ters taraftan mübalağava düserek hukuku sadece solans alemine ithal ediyor. Traite, c. I, S. 64. 
tığı cahil ve șekilperest hâkim tipi olan Brid'oison'a benzetecektir. Bu hal bilhassa usul hukuklarında kendini gösterecek ve meselầ beyyineler de sırf șeklî olacak ve beyyine serbestisi sistemi ortadan kalkacaktır (31).

3-Hukukta gaî (téléologique) mülâhazaların yeri olmadığı fikri de șiddetle tenkit edilmiștir.— Kelsen'in müfrit șekilciliği onu böyle bir neticeye vardırmaktadır. Filhakika, müellife göre, hukuk ilmi bir hadisenin sadece şekli ile meșgul olur. O hadisenin muhtevası, sosyolojinin, tarihin veya siyaset ilimlerinin mevzuunu teșkil eder. Hukuk mefhumları, hiç bir zaman sarih bir șekilde tesbit edilemiyecek olan muhtevalarına değil șeklî vasıflara istinat ettirilmelidir.

Hukuk mefhumlarının șeklî vasıflara istinat ettirilmeleri fikri doğru olabilir. Ancak, bu șeklî vasıfların tesbitinde bir hukuk müessesesinin hizmet edeceği sosyal gaye ihmal edilemez. Sosyal gayelerinden tecerrüt ederek hukukî mefhumlardan faydalanmak imkânsızdır. Ezcümle, hukukun sosyal rolünden tecerrüt ederek hukukî mükellefiyetten bahsedilemez. Jellinek bile, «insanlar arasındaki münasebetlerin cevherine varmadan» ilmî krymeti olan hukukî neticeler istihsal etmenin kaabil olmadığını söylemektedir (32). Kanunların tefsiriyle meșgul olmuş her hukukçu, bir kanun hükmünün ekseriya bir çok bașka başka tefsirlere meydan verebilecek șekilde olduğunu ve bu takdirde, kanunun ne maksatla yapıldığı, umumiyetle hukukun gayesi, müșterek iyilik; adalet; emniyet gibi gaye mülâhazasının mühim rol oynadığını pek güzel bilir. Ancak Kelsen. tefsirin müsbet hukukun bir tahlili olduğunu ve tefsir sayesinde mevcut kaidelere istinat ederek yeni kaideler elde edilegileceğini, hattâ kanunlarda boşlukların (lacune) mevcut bulunacağını kabul etmiyor. Müellife göre, kanunda boșluk yoktur. Boșluk denilen șey hukukçunun, kanunun yerine kendi ideolojisini tatbik etmek için kullandığı bir formüldür. Bu düșünüș tarzı, medenî hukukun tefsiriyle pek az meșgul olmuș «hukukçu - filozof»a mahsus bir diușünce tarzıdır. Pratikte ekseriya, tatbik olunması lâzımgelen kanun derin bir tefsirî tahlil neticesinde butlunabilir. Kelsen: «Kanun saçma bir muhtevaya sahip olabilir, bu takdirde hiç bir tefsir ona bir mâna veremez» dediği zaman da hukukçudan ziyade filozofa hitap etmektedir. Zira bilindiği gibi, hukukçunun rolü, her hal ve kârda, mükemmel olmasa bile kabul edilebilecek; yani umumiyetle hukukun gayesine en uygun bir hal çaresi bulmaktır. Eğer, kanunların tefsiri ve hukuk normlarının mantıkî istidlâl-

(31) Hauriou. Précis de droit constitutionnel, Paris 1929, Préface, S. 9.10

(32) Peretiatkowicz, op. cit., S. 233. 
ler sayesinde teşmili umumiyetle kabul edilmemiş olsa idi, bütün Roma hukuku sistemi hiç bir zaman meydana gelemezdi. Çünkü, modern Avrupa kültürü üzerinde bu derece kuvvetli bir tesir icra eden bu sistem, doğrudan doğruya on iki levha kanununun gaiyet geniș bir şekilde gaî (téléologique) tẹfsirinden vücude gelmiștir. Binaenaleyh, Kelsen tarafından teklif edilen gaye mefhumunun hukuk sahası dıșında bırakılması kabul edilemez ve bu hukuk nazariyesinin başlica çürük noktalarından birini teșkil eder. Hukukî araștırmalar için téléologique metod, yani gaye mülâhazası esastır (33).

4 - Kelsen'in hukuk normunun mümeyyiz vasfı hususunda ileri sürdüğü fikirler de itirazları mucip olmuștur. Filhakika, hukuk normunun mümeyyiz vasfı, müellfin iddia ettiği gibi, o norma itaat etmemenin «mümkün olabilmesinde» değildir. Zira, bir norma daima itaat edilmesi onun norm olmak vasfinı ortadan kaldırmaz. O norm mevcut iken ona uygun olarak yapılan tasarruflar, eğer o norm mevcut olmasaydı belki de aynı şekilde yapılmazdı. Bir hukuk normu vazedilirken ideal olan herhalde ve bilâistisna o norma riayet edilmesidir ve bir norma ne kadar fazla riayet olunursa, o norm, hakikî mahiyetini o derece iktisap eder ve tabiî kanuna yaklașır. Esasen bu bakımdan da hukuk normu ile tabiat kanununu birbirlerine tamamen zıd olarak göstermek hatalıdır. Hûlâsa, hukuk normuna itaat etmemenin «mümkün olabilmesi» keyfiyeti hakikatte varid olsa dahi, bir hukuk normunun mümeyyiz vasfı olarak ele alınması doğru değildir. Zira bu cihet, hukuk normunun hakikî mahiyetini bize göstermez (34).

Bundan başka Kelsen, hukuk normlarının rolünü de değiştirmiştir. Zira; birinci derecedeki normlar, müellifin iddia ettiği gibi; müeyyide koyan ve bu müeyyidenin tatbikini emreden normlar değil, bilâkis, Kelsen'in ikinci derecede normlar dediği, ferdlere bazı emir ve nehilerde bulunan normlardır. Müellif, normların sırasını değiștirmek suretiyle hukuka sadece menfí bir mahiyet vermiștir. Ona göre hukuk, yainız «hukukî hayatın marazlariyle» pathologie'siyle uğrașır. Halbuki, normların esası ceza tatbikinde değil, verdikleri emir ve nehilerdedir. Kaldı ki, her hukuk normu bir bütün olarak hukukun haiz bulunduğu vasıfları haiz olamaz. Kelsen'in bu telâkikisi, karșllğında müeyyide olmamakla beraber hukukî vaziyetler yaratan bir çok hukuk kaidesini hukuk sisteminin d1şında birakmaktadir (35).

(33) Peretiatkowicz, op. cit, S. 234.

(34) Simonovitch, Hold-Ferneck, den naklen, op. cit, S. 122.

(35) Simonovitch, Hold-Ferneck, den naklen, op. cit., S. 123.124. 
5 - Kelsen'in iddia ettiği gibi hukukun sadece bir normlar sistemi olduğu da kabule șayan değildir. Hakikatte, hukuk denilen șey; hem bir normlar sistemi. hem de, bu normlara uyularak yapilan tasarruflardir. Hukuk normlarını; taallûk ettikleri vakıalardan ayırmak imkânsızdır. $\mathrm{Bu}$ o kadar doğrudur ki, bizzat Kelsen dahi vakıalar âleminde cereyan eden șeyleri nazaritibara almak mecburiyetinde kalmıștır. Meselâ «müessiriyet» vakıalar âlemine dahildir, Hukuk bir normlar sistemi değil, normlarla organların birbirlerini takip ettikleri bir sistemdir. Hukukî meratibin en sonunda hukuk normları gereğince ifa edilmiș vakıalar vardır. Bu vakıalar zarurî olarak hukukî vakıalardır, çünkü hukukî vaziyetler tevlit ederler. Meselâ adlî veya idarî kararlar mucibince veya mukaveleler mucibince yapılan tasarruflar bu kabildendir. Görülüyor ki hukuk sadece «olması lâzımgelen» ile meșgul olmuyor «olan»1 da ihtiva ediyor (36).

6 - Kelsen'in sübjektif hakları inkâr etmesi keyfiyetinin neticeleri çok tehlikeli olabilir. Filhakika sübjektif hakların inkârı yalnız siyasî değil fakat medenî hürriyeti bile ortadan kaldırabilir. Hukukun ferdiyetçi esasın terketmek, ister istemez; cemiyetin ferdiyetçi esasını inkâra sevkeder. Şahıs hürriyeti, bir takım haklarla ifade edilemediği takdirde; mevcut değil addolunabilir (37). Bu sưretle hürriyetin üstünlüğünün yerine otoritenin üstünlüğü kaim oluyor demektir.

7 - Devlet ile hukukun aynı șey olduğu iddiası da aynı neticeyi doğurur. Filhakika, Duguit'nin de ifade ettiği veçhile; bu takdirde devleti hukuk ile takyit imkânı kalmaz(38). Zira, artık devletin dıșında hukuk yoktur. Hukuk, müsbet hukuka; yani devletin kanunlarına inhisar etmektedir. Halbuki devletin hukukan takyit edilebilmesi için hukukun devlete üstün ve ondan hariç olması lâzımgelir. Kaldı ki, devlet; sadece hukukî normlar vazetmekle iktifa eylenez. Devletin faaliyeti yanmda bu hukukî normların derpiş etmedikleri bir çok tasarruflar da vardır. Meselâ, harp halinde. devletin faaliyetini düșünmek, yukarıdaki iddiayı ispata kâfidir. Vakıa, Kelsen ile birlikte, hukuk normları sisteminin devlet mefhumunun unsurlarından birini teșkil eylediğini kabul edebiliriz. Ancak, devletin sadece bir hukukî normlar sistemi olduğunu kabule imkân yoktur. Çünkü, devletin aslî unsurları meyanına, muayyen bir ülke üzerinde ve kendisine tabi olan ferdlerin iradelerinden müstakil olarak tatbik edilen üstün bir kudret de girer. Normlar nizamı, fiilî ve

(36) Coste - Floret, op. cit, S. $40-41$

(37) Hauriou, op, cit., Préface 9-10, ve S. 11.

(38) Duguit. Traité, C. I, S. 44 
siyasî bir kudrete istinat etmelidir ki müsbet hukuk bahis mevzuu olabilsin. Müsbet hukuk tabiri ancak müșahhas vakalara, fiilî ve üstün bir kudrete veya bu kudretin organlarına istinat eden bir hukuka izafe olunabilir (39).

8 - Nihayet, Kelsen'in devlet ile hukukun tekçi görüșünün bir neticesi olarak ileri sürdügü, devletin șe'ni bir varlık olmayı sadece ideal, aklî bir mevcudiyete sahip bulunduğu hususundaki düșünce de yanlıștır. Devlet, mantıkî bir sistem değil, bir sosyal varlıktır ve bizim dışımızdadır. Müellif, insanlardaki devlet fikrini realitede mevcut devlet müessesesi ile birbirine karıștırmaktadır. Devlet bir vakadır, sosyal ve tarihî bir mut'adır ve bu bakımdan bizim sübjektif âlemimiz dıșında bir varliktır (40). Halbuki, Kelsen devleti sadece bir hukuki normlar nizamı olarak görmekte ve ona göre bu normlar nizamı üstün bir temel - normdan istịdlâl edilmektedir. Bu temel - norm fikri de çürüktür. Zira, ya temel normun objektif mevcudiyetini kabui etmek ve onu hukukî nizama idhal etmek lâzımdır ( $k i$ müellif bu hususu reddediyor), veya bu normu tamamen farazî olarak ele almak icabeder. Ancak bu sonuncu takdirde ona objektif bir mahiyet tanımak imkânsızdır. Böyle olunca, bir faraziyenin gerek hukuka gerek devlete mesnet, esas olmasinı mantık kabul etmez. Zira, bir faraziye olan temel-norm devletin esası addolunursa, devletin mevcudiyeti için, bütün tebaanın o faraziyeyi kabul etmeleri lâzımdır. Halbuki devletin mevcudiyeti için ferdlerin onu tanımaları șartı bahis mevzuu olamaz. Çünkü devlet bir vakıadır. Bu farazî temel-normun pratik bakımdan da mahzurları vardır. Filhakika, bu görüș tarzı, fiiliyatta idare edenlerin keyfî tahakkümüne müncer olabilir. Bütün mesele, temel - norm olarak kabul edilecek düsturdadır. $\mathrm{Bu}$ düstur mutlakiyete, istibdada, keyfî idareye sevkedebilecek bir düstur oldu mu bütün hukuk sistemi de aynı vasıfları haiz olsa hukukan mer'i ve muteber addedilmesi lâzımgelecektir.

Bütün bu tenkitlere rağmen, Kelsen'in hukuk ve devlet teorisinde metot meselelerini birinci plâna geçirmek gibi bir hizmeti dokunduğu söylenebilir. Devletin hukukî mahiyetini bütün inceliğiyle belirtmiș ve hukukun derece derece tekâmülü hakkında doğru mülâhazalar ileri sürmüştür. Ancak ne yazlk ki, devletin hukukî mahiyetini belirtmek isterken bu müessesenin sosyal bir realite olduğunu ve mudil bir bünyesi bulunduğunu gözden kaçırmıştır.

(39) Peretiatkowicz, op. cit, S. 230.

(40) Simonovitch, Erich Voegelin'den naklen, op. cit, S. 129 